\title{
KADAR SERUM SELENIUM PADA REMAJA AKHIR USIA 17-19 TAHUN BERDASARKAN STATUS OBESITAS DAN STUNTING
}

\author{
Yusuf Hidayat $^{1}$, M. Sulchan ${ }^{1}$, Binar Panunggal ${ }^{1}$ \\ ${ }^{1}$ Departemen Ilmu Gizi, Fakultas Kedokteran, Universitas Diponegoro \\ Jln. Prof. H. Soedarto, SH., Semarang, Telp (024) 76402881, Email : gizifk@undip.ac.id
}

\begin{abstract}
Background : Obese and stunted adolescents had been found have decreased body selenium level. Impaired selenium status can lead to oxidative stress which is main precursor of many metabolic disorders. This study was aimed to examine the difference of selenium serum level among 17-19 years adolescents based on obesity and stunting status.

Methods : This was cross-sectional study performed with 88 adolescents aged 17-19 years which were divided into 4 groups based on obesity and stunting status. Obesity was determined by WHtR $>0.5$ for female and $>0.51$ for male. Stunting was determined by Height-for-Age >-2 SD. ICP-OES was used to measuring selenium serum level. The difference of selenium serum level was analized using one-way Annova.

Results : The means of serum selenium level in stunted obesity, stunted-non obesity, non stunted-obesity, and non stuntednon obesity groups were $277,5 \pm 96,4 \mathrm{ng} / \mathrm{ml}, 418 \pm 93,4 \mathrm{ng} / \mathrm{ml}, 304 \pm 64,9 \mathrm{ng} / \mathrm{ml}$, and $330 \pm 112,2 \mathrm{ng} / \mathrm{ml}$, respectively. There was significant difference on selenium serum within the groups.

Conclusions : All groups had selenium serum level above normal range. Both stunted-obesity and non stunted-obesity group had lower selenium serum level than non stunted-non obesity group, while stunted-non obesity had higher selenium serum level than non stunted-non obesity group.
\end{abstract}

Keywords : obesity, stunting, adolescence, selenium serum

\section{ABSTRAK}

Latar Belakang : Remaja yang obesitas dan stunting ditemukan mengalami penurunan kadar selenium di tubuh. Penurunan kadar selenium berdampak terhadap kejadian stress oksidatif yang merupakan prekursor berbagai masalah kesehatan. Penelitian ini bertujuan mendeskripsikan perbedaan kadar serum selenium pada remaja akhir usia 17-19 tahun berdasarkan status obesitas dan stunting.

Metode : Penelitian cross-sectional ini dilakukan pada 88 remaja usia 17-19 tahun yang dibagi dalam 4 kelompok berdasarkan status obesitas dan stunting. Obesitas ditentukan dengan nilai WHtR $>0.5$ untuk perempuan dan $>0.51$ untuk laki-laki. Stunting ditentukan dengan TB/U >-2 SD. Kadar serum selenium ditentukan menggunakan ICP-OES. Perbedaan kadar serum selenium dianalisis dengan uji Annova.

Hasil : Rerata kadar serum selenium pada kelompok stunted-obesity sebesar 277,5 $\pm 96,4$, stunted-non obesity 418 $\pm 93,4$,

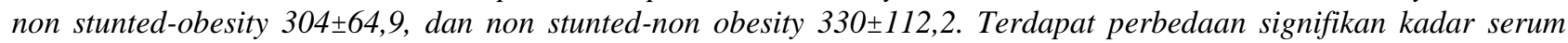
selenium pada kelompok.

Simpulan : Kadar serum selenium pada seluruh kelompok tergolong lebih tinggi dibanding nilai normal. Kelompok stunted-obesity dan non stunted-obesity memiliki kadar serum selenium yang lebih rendah dibanding kelompok non stunted-non obesity, sedangkan kelompok stunted-non obesity memiliki kadar selenium serum yang lebih tinggi dibanding kelompok non stunted-non obesity.

Kata kunci : obesitas, stunting, remaja, serum selenium

\section{PENDAHULUAN}

Masa remaja merupakan masa transisi dari masa anak-anak ke masa dewasa yang ditandai dengan adanya pubertas berupa terjadinya perubahan komposisi tubuh terutama penyebaran lemak tubuh, peningkatan aktivitas hormon-hormon reproduksi yang berdampak pada penurunan sensitivitas insulin, peningkatan lipolisis di liver, serta peningkatan jumlah asam lemak bebas dalam sirkulasi tubuh ${ }^{1}$. Perubahan-perubahan tersebut menyebabkan remaja dianggap sebagai periode kritis terhadap terjadinya peningkatan berat badan berlebih dan obesitas ${ }^{2}$. Obesitas merupakan suatu kondisi yang diakibatkan oleh adanya penumpukan lemak tubuh berlebihan. Remaja yang obesitas berisiko mengalami obesitas dan penyakit degeneratif pada saat dewasa ${ }^{3}$. Berdasarkan data Riset Kesehatan Dasar (Riskesdas) tahun 2013, remaja usia 16-18 tahun yang berstatus gemuk berdasarkan IMT/U sebesar 7.3\%. Angka ini mengalami peningkatan dibanding pada tahun 2010 dengan prevalensi sebesar $1.4 \%{ }^{4}$.

Masalah gizi lain yang juga terjadi di kalangan remaja Indonesia adalah stunting. Prevalensi stunting di Indonesia masih tergolong tinggi yaitu sebesar $31,4 \%$ pada remaja usia $16-18$ tahun $^{4}$. Stunting pada anak-anak sering dikaitkan dengan risiko terjadinya 
obesitas di masa depan. Penderita stunting mengalami gangguan yang ditandai dengan oksidasi lemak yang lebih rendah jika dibandingkan dengan penderita nonstunting ${ }^{5}$. Gangguan oksidasi lemak jika diikuti dengan asupan makanan tinggi lemak pada penderita stunting akan menyebabkan lemak lebih cepat disimpan dan menyebabkan penumpukan lemak dan melatarbelakangi terjadinya obesitas-stunting ${ }^{5}$.

Salah satu gangguan yang terjadi pada penderita stunting dan obesitas adalah stress oksidatif. Stress oksidatif merupakan keadaan dimana terdapat ketidakseimbangan antara oksidan dengan antioksidan dalam sel akibat berlebihnya jumlah reactive oxygen species (ROS) ${ }^{6}$. Stress Oksidatif terlibat dalam proses-proses patologis seperti pada sindrom metabolik, diabetes, dan penyakit jantung ${ }^{7}$. Makhluk hidup memiliki mekanisme untuk melindungi biomolekul dari efek stress oksidatif melalui antioksidan. Terdapat dua jenis antioksidan yaitu antioksidan endogen yang berupa enzim-enzim antioksidan, serta antioksidan eksogen yang berupa zat-zat gizi antioksidan. Selenium merupakan salah satu zat gizi antioksidatif yang berperan dalam pencegahan stress oksidatif yaitu sebagai bagian integral dari Se-dependent enzyme diantaranya Glutathion Peroxidase (GPx) dan Thioredoxin Reductase (TR) ${ }^{8}$.

Beberapa penelitian mengenai kadar selenium pada penderita obesitas maupun stunting sudah dilakukan dimana hasil tersebut membuktikan bahwa terdapat penurunan kadar selenium pada penderita obesitas maupun stunting ${ }^{9-14}$. Akan tetapi masih sedikit penelitian yang membandingkan perbedaan kadar selenium pada remaja berdasarkan status obesitas dan stunting. Kadar selenium yang rendah dapat berdampak pada peningkatan risiko diabetes mellitus tipe 2 dan sindrom metabolik melalui peningkatan stress oksidatif ${ }^{12}$. Oleh karena itu, penelitian ini dilakukan untuk melihat perbedaan kadar serum selenium pada kelompok remaja berdasarkan status obesitas dan stunting yang dibagi menjadi stunted-obesity, stunted-non obesity, non stunted-obesity, dan non stunted-non obesity.

\section{METODE}

Penelitian ini termasuk dalam ruang lingkup keilmuan gizi masyarakat dengan menggunakan desain penelitian cross-sectional. Populasi dalam penelitian ini adalah seluruh mahasiswa baru Universitas Diponegoro tahun ajaran 2017/2018 yang berusia 17-19 tahun. Sampel diambil dengan cara consecutive sampling. Besar sampel dalam penelitian ini adalah 88 sampel yang dibagi dalam 4 kelompok yaitu 22 sampel stunted-obesity, 22 sampel stuntednon obesity, 22 sampel non stunted-obesity, dan 22 sampel non stunted-non obesity
Kriteria inklusi penelitian ini adalah tidak sedang mengkonsumsi obat-obatan atau suplemen yang mempengaruhi kadar selenium tubuh, tidak merokok, tidak mengkonsumsi alkohol, dan tidak memiliki riwayat penyakit metabolik pada subjek maupun keluarga, dan tidak sedang melakukan aktivitas fisik dengan intensitas berat. Kriteria ekslusi adalah subjek mengundurkan diri dalam penelitian, subjek sakit atau meninggal dunia saat penelitian berlangsung, dan subjek pindah atau keluar dari universitas. Setiap subjek terpilih diberikan informed consent sebagai tanda subjek setuju ikut serta dalam penelitian, pembuatan ethical clearance disetujui oleh Komite Etik Penelitian Fakultas Kedokteran Universita Diponegoro/RSUP dr. Kariadi Semarang.

Variabel terikat pada penelitian ini adalah kadar serum selenium, sedangkan variabel bebas adalah status obesitas dan stunting. Obesitas didefinisikan jika subjek memiliki Waist-to-height rasio (WHtR) yang dihitung melalui perbandingan lingkar pinggang dengan tinggi badan sebesar $\geq 0,5$ untuk perempuan dan $\geq 0,51$ untuk laki-laki ${ }^{15}$. Stunting didefinisikan jika subjek memiliki $z$-score tinggi badan berdasarkan usia $(\mathrm{TB} / \mathrm{U})<-2 \mathrm{SD}^{16}$. Persentase kecukupan asupan zat-zat gizi (Protein, $\mathrm{Se}, \mathrm{Cu}, \mathrm{Zn}, \mathrm{Fe}, \mathrm{Mn}$, Vitamin C, dan Vitamin E) juga dianalisis sebagai faktor perancu.

Pengambilan data dilakukan pada bulan Agustus 2017 sampai Maret 2018 meliputi pengukuran antropometri, pengambilan data persen kecukupan asupan zat gizi, dan pengambilan darah. Pengukuran antropometri subjek dilakukan untuk menentukan status obesitas berdasarkan WHtR dan status stunting berdasarkan z-score TB/U. Pengukuran lingkar pinggang dilakukan dengan pita ukur dengan ketelitian $0,1 \mathrm{~cm}$ sedangkan tinggi badan diukur dengan menggunakan microtoise dengan ketelitian $0,1 \mathrm{~cm}$. Pengukuran antropometri dilakukan sebanyak $2 x$ untuk meminimalisir bias dan kemudian hasil pengukuran dirata-rata. Penentuan status stunting dilakukan menggunakan software WHO AnthroPlus. Pengambilan data persen kecukupan asupan zat gizi dilakukan menggunakan Semi Quantitative Food Frequency Questionnaire dengan menanyakan riwayat asupan makanan dalam jangka waktu satu bulan sebelum pengambilan data dan diolah menggunakan software Nutrisurvey 2007. Data hasil asupan subjek kemudian dibandingkan dengan kebutuhan zat gizi sesuai dengan Angka Kecukupan Gizi (AKG) 2013. Pengambilan sampel darah dilakukan oleh petugas ahli yang berasal dari Laboratorium GAKI FK Undip Semarang. Pengambilan darah dilakukan dalam kondisi fasting selama 10 jam di malam hari dan hanya diperbolehkan meminum air putih. Darah diambil melalui pembuluh vena di lengan (vena mediana 
cubiti) pada jam $06.00-09.00$ WIB sebanyak 5 cc. Sampel darah yang telah terambil disimpan dalam freezer. Darah lalu disentrifugasi untuk memperoleh serum darah kemudian diencerkan dengan air steril dengan perbandingan 1:20. Analisis kadar serum selenium dilakukan di Laboratorium Kimia Universitas Negeri Semarang dengan menggunakan Perkin-Elmer Optima 8300 Inductively coupled plasma optical emission spectroscopy (ICP-OES) dengan membaca pada panjang gelombang 196.026 $\mathrm{nm}$. Kadar normal serum selenium berkisar antara 70$150 \mathrm{ng} / \mathrm{ml}$.

Distribusi kenormalan data dilihat menggunakan Kolmogorov-Smirnov. Analisis univariat dilakukan untuk mendeskripsikan rerata, median, dan standar deviasi variabel $\mathrm{WHtR}, \mathrm{TB} / \mathrm{U}$, kadar serum dan persen kecukupan asupan zat gizi di tiap kelompok. Analisis perbedaan kadar serum selenium antarkelompok dilakukan menggunakan Uji statistik parametrik Annova dilanjut dengan post-hoc test Bonferroni. Hubungan antara variabel WHtR, $\mathrm{TB} / \mathrm{U}$, dan kecukupan asupan zat gizi dengan kadar selenium dianalisis dengan uji Pearson dan Spearman. Pengujian dilakukan pada tingkat kepercayaan $95 \%$ dan menggunakan software analisis statistik.
HASIL

Skrining dilakukan pada sebanyak 1848 mahasiswa pada 8 fakultas di Universitas Diponegoro. Mahasiswa yang diikutsertakan menjadi subjek merupakan mahasiswa berusia 17-19 tahun. Gambaran distribusi subjek berdasarkan status obesitas dan stunting dapat dilihat pada Tabel 1.

Tabel 1. Distribusi subjek berdasarkan status obesitas dan stunting pada populasi

\begin{tabular}{lcc}
\hline Kelompok & Jumlah & Persentase \\
\hline Stunted-Obesity & 53 & $2,86 \%$ \\
Stunted-non Obesity & 201 & $10,87 \%$ \\
Non Stunted-Obesity & 261 & $14,13 \%$ \\
Non Stunted-non Obesity & 1333 & $72,14 \%$ \\
Total & 1848 & $100 \%$ \\
\hline
\end{tabular}

Tabel 1 menunjukkan bahwa persentase subjek yang mengalami stunted-obesity dalam populasi sebanyak $2,86 \%$. Persentase subjek yang mengalami stunted-non obesity dalam populasi sebesar $10,87 \%$. Angka tersebut lebih rendah dibanding angka kejadian stunting pada remaja usia 16-18 tahun secara nasional yaitu sebesar 31,4 pada tahun 2013. Akan tetapi persentase subjek yang mengalami non stuntedobesity pada populasi hampir dua kali lipat lebih tinggi angka kejadian obesitas secara nasional pada remaja usia 16-18 tahun berdasarkan IMT/U pada tahun 2013 sebesar $7,3 \% \%^{4}$.

Tabel 2. Perbandingan nilai antropometri dan kecukupan asupan subjek

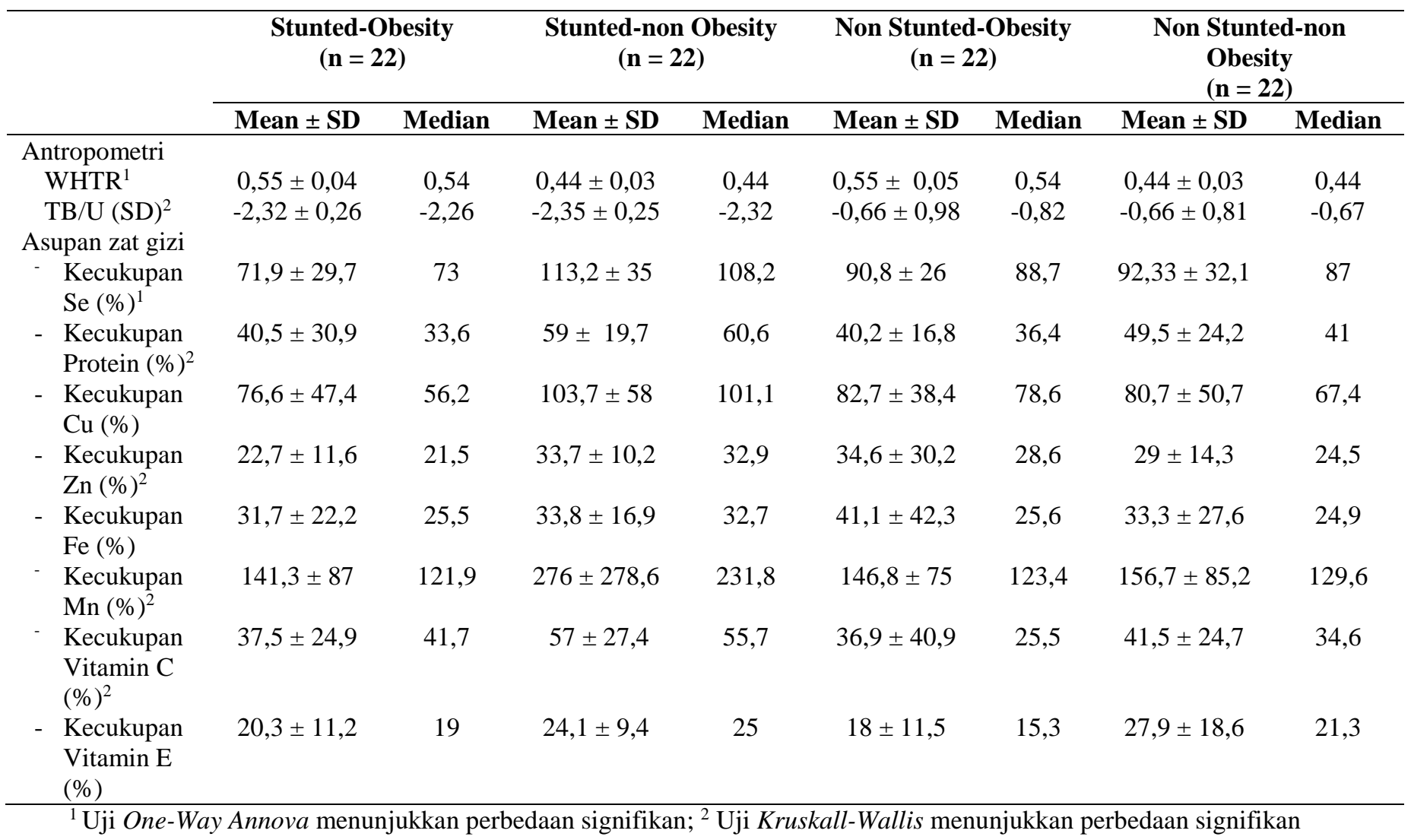


Perbandingan nilai antropometri dan persentase kecukupan asupan disajikan dalam Tabel 2. Rerata WHTR tertinggi terdapat pada kelompok stunted-obesity dan non stunted-obesity. Sedangkan rerata $\mathrm{TB} / \mathrm{U}$ terendah terdapat pada kelompok stunted-non obesity. Perbandingan persentase kecukupan asupan zat gizi didapat hasil bahwa hanya terdapat perbedaan pada variabel persentase kecukupan asupan Se, protein, Zn, Mn, dan Vitamin E. Kelompok stunted-non obesity memiliki rerata persentase kecukupan asupan $\mathrm{Se}$, protein, $\mathrm{Cu}, \mathrm{Mn}$, dan Vitamin E yang tertinggi dibanding rerata kelompok lainnya.

Tabel 3 menunjukkan kadar serum selenium pada kelompok dimana didapat semua kelompok memiliki kadar serum selenium yang berada pada kategori tinggi $(>150 \mathrm{ng} / \mathrm{ml})$. Rerata kadar serum selenium tertinggi terdapat pada kelompok stuntednon obesity, sedangkan yang terendah adalah kelompok stunted-obesity. Rerata kadar serum selenium pada kelompok stunted-obesity dan non stunted-obesity lebih rendah dibanding rerata kadar serum selenium pada kelompok non stunted-non obesity. Terdapat perbedaan signifikan pada kadar serum selenium pada tiap kelompok $(p=0.001)$ dimana setelah dilakukan uji lanjut (post-hoc) Bonferroni, perbedaan hanya terdapat antara kelompok stunted-non obesity dengan kelompok lainnya.

Table 3. Perbedaan kadar serum selenium pada kelompok

\begin{tabular}{llcccc}
\hline & & n & Mean \pm SD & Median & $\boldsymbol{p}$ \\
\cline { 2 - 5 } Status Obesitas dan & & 22 & $277,5 \pm 96,4$ & 275 \\
Stunting & Stunted-obesity & 22 & $418 \pm 93,4$ & 412,5 & $0.001^{1}$ \\
& Stunted-non obesity & 22 & $304 \pm 64,9$ & 313,5 & 346.5 \\
& Non stunted-obesity & 22 & $330 \pm 112,2$ & 3 \\
& Non stunted-non obesity & &
\end{tabular}

${ }^{I} \mathrm{Uji}$ one-way Annova

Tabel 4. Hubungan kadar serum Se dengan variabel antropometri dan persentase kecukupan asupan

\begin{tabular}{|c|c|c|}
\hline & \multicolumn{2}{|c|}{ Kadar Serum Se } \\
\hline & $r$ & $p$ \\
\hline WHTR $^{\mathrm{a}}$ & $-0,270$ & 0.005 \\
\hline $\mathrm{TB} / \mathrm{U}(\mathrm{SD})^{\mathrm{b}}$ & $-0,210$ & 0.025 \\
\hline Kecukupan Se $(\%)^{\mathrm{a}}$ & 0,232 & 0.015 \\
\hline Kecukupan P $(\%)^{\mathrm{b}}$ & 0,232 & 0.015 \\
\hline Kecukupan $\mathrm{Cu}(\%)$ & 0,168 & 0.059 \\
\hline Kecukupan Zn (\%) & 0,154 & 0.076 \\
\hline Kecukupan Fe (\%) & 0,027 & 0.402 \\
\hline Kecukupan Mn $(\%)^{\mathrm{b}}$ & 0,260 & 0.007 \\
\hline Kecukupan Vit C (\%) & 0,320 & 0.001 \\
\hline Kecukupan Vit E (\%) & 0,166 & 0.061 \\
\hline
\end{tabular}

Tabel 4 menunjukkan hubungan antara variabel kadar serum Se dengan variabel antropometri (WHTR dan TB/U), dan variabel persen kecukupan asupan zat gizi sebagai perancu. Hubungan yang signifikan ditunjukkan antara kadar serum Se dengan WHTR $(r=-0,270, p=0.005)$. Dengan demikian WHTR berkorelasi negatif dengan kadar serum Se dengan kekuatan korelasi yang rendah. Korelasi negatif juga ditunjukan antara kadar serum Se dengan TB/U dengan kekuatan korelasi yang lebih rendah $(r=-0,210, p=0.025)$. Variabel persentase kecukupan asupan zat gizi yang berhubungan signifikan dengan kadar serum Se diantaranya persentase kecukupan $\mathrm{Se}, \mathrm{P}, \mathrm{Mn}$, dan Vitamin C dengan korelasi positif dan kekuatan korelasi tertinggi terdapat pada hubungan antara persentase kecukupan vitamin $\mathrm{C}$ dengan kadar serum Se. Tidak terdapat hubungan signifikan antara masing-masing variabel persentase kecukupan $\mathrm{Cu}$, $\mathrm{Zn}, \mathrm{Fe}$, dan Vitamin E dengan kadar serum Se.

\section{PEMBAHASAN}

Berdasarkan studi ini, ditemukan bahwa persentase remaja yang mengalami obesitas pada populasi sebesar $14,13 \%$ dan remaja yang mengalami stunting sebesar $10,87 \%$. Persentase remaja yang stunting tidak lebih tinggi daripada prevalensi nasional stunting pada remaja usia 16-18 tahun. Remaja yang stunting berisiko mengalami gangguan oksidasi lemak yang menyebabkan lemak lebih cepat disimpan dan berisiko menjadi obesitas ${ }^{5}$. Sementara itu, persentase remaja yang mengalami obesitas pada populasi ditemukan hampir dua kali lebih tinggi dibanding prevalensi nasional. Hal ini mungkin disebabkan karena kecenderungan kurang makan sayur dan buah pada penduduk Indonesia yang masih tinggi pada tahun 2013 yaitu sebesar $93,6 \%$ penduduk $\geq 10$ tahun kurang makan sayur dan buah. Angka tersebut juga tidak mengalami perubahan dibanding pada tahun $2007^{4}$. Selain itu proporsi penduduk $\geq 10$ tahun yang mengkonsumsi makanan berlemak lebih dari satu kali per hari di Indonesia juga masih tinggi yaitu sebesar $40,7 \%$ pada tahun $2013^{4}$. Obesitas pada remaja dapat berdampak pada terjadinya obesitas dan masalah kesehatan lain di masa dewasa. 
Studi ini mendapat hasil bahwa seluruh subjek memiliki kadar serum selenium yang diatas nilai normal. Kadar serum selenium normal yang dibutuhkan tubuh adalah $70-150 \mathrm{ng} / \mathrm{mL}$ untuk fungsi glutathion peroksidase yang optimal ${ }^{17,18}$. Kadar serum yang tergolong tinggi pada semua subjek mungkin disebabkan oleh rerata persen kecukupan asupan subjek yang mencapai $>90 \%$ pada semua kelompok kecuali kelompok stunted-obesity yang hanya mencapai $71,9 \%$. Hal ini disebabkan tingkat selenium dalam serum sangat dipengaruhi oleh asupan selenium ${ }^{17}$. Kadar serum selenium juga diketahui dapat dipengaruhi oleh kondisi geografis. Hal ini disebabkan kandungan selenium dalam tanah berbeda-beda pada setiap daerah sehingga konsentrasi selenium dalam darah pada penduduk di seluruh dunia sangat bervariasi ${ }^{19,20}$. Sebagai contoh rerata kadar selenium darah pada penduduk Finlandia sebesar 41,7 ng/mL, pada penduduk kanada 158,2 $\mathrm{ng} / \mathrm{mL}$, dan pada penduduk China 0,15-0,25 $\mathrm{mmol} / \mathrm{L}^{21}$. Studi yang dilakukan di Brazil juga mendapatkan hasil bahwa kadar selenium darah pada sebagian besar subjek berada diatas nilai normal dengan range $142.1-2029.3 \mathrm{ng} / \mathrm{mL}^{22}$.

Hasil pada penelitian ini menunjukan bahwa kadar serum selenium pada kelompok stunted-non obesity diketahui lebih tinggi secara signifikan dibanding pada kelompok lainnya setelah dilakukan pengujian post-hoc. Hasil ini bertolakbelakang dengan temuan pada penelitian-penelitian lain. Stunting merupakan masalah gizi yang disebabkan oleh beberapa faktor seperti ketidakadekuatan asupan gizi, infeksi, dan kurangnya interaksi dari ibu dan anak $^{13}$. Berdasarkan studi, subjek yang stunting memiliki biomarker stress oksidatif seperti enzimenzim antioksidan yang lebih rendah dibanding kelompok kontrol ${ }^{13}$. Hal ini menyebabkan adanya ketidakseimbangan antioksidan-oksidan sehingga menyebabkan stress oksidatif. Stress oksidatif tersebut juga dipicu dengan kurangnya asupan seperti zinc dan tembaga sebagai kofaktor dari enzim antioksidan $^{13}$. Selain itu, pada penelitian lain disebutkan bahwa terdapat penurunan kadar trace element dalam serum pada penderita stunting terjadi akibat adanya peningkatan level sitokin-sitokin proinflamasi ${ }^{13}$. Kadar serum selenium yang tinggi pada kelompok stunted-non obesity di penelitian ini mungkin disebabkan karena sebagian besar rerata asupan zat gizi yang tertinggi pada kelompok stuntednon obesity. Sebuah studi menjelaskan bahwa asupan makanan pada individu stunting lebih besar ${ }^{23}$. Hal tersebut dapat disebabkan lemak di dalam tubuh yang rendah menstimulasi sinyal yang merangsang terjadinya hiperfagia ${ }^{24}$. Nukleus lateral hipotalamus akan dirangsang untuk memfasilitasi terjadinya reaksi kimiawi dalam pengaturan asupan makanan dan persepsi kenyang serta mempengaruhi sekresi hormon yang terlibat dalam pengaturan keseimbangan energi dan metabolisme. Hormon yang disekresi diantaranya Ghrelin yang memicu aktivasi neuropeptide $Y$ (NPY) dan Agouti-related protein (AgRP) yang dapat meningkatkan nafsu makan ${ }^{25}$. Asupan selenium sangat berpengaruh terhadap kadar serum selenium di dalam tubuh, sehingga semakin tinggi asupan selenium maka kadar serum selenium juga akan semakin tinggi. Selain itu defisiensi kadar mineral pada penderita stunting biasanya muncul pada usia kurang dari 5 tahun akibat peningkatan kebutuhan zat gizi untuk pertumbuhan dan perkembangan serta adanya infeksi, serta pada usia tersebut penderita stunting belum dapat memenuhi kebutuhan asupannya sendiri dibanding pada usia remaja ${ }^{13}$.

Kadar serum selenium pada kelompok non stunted-obesity dan stunted-obesity pada penelitian ini lebih rendah dibandingkan kelompok non stuntednon obesity. Akan tetapi, setelah dilakukan uji post hoc, tidak terdapat perbedaan yang signifikan pada kelompok-kelompok tersebut. Hasil penelitian ini sejalan dengan penelitian-penelitian sebelumnya, dimana pada kelompok obesitas kadar serum selenium lebih rendah secara signifikan dibanding kelompok normal ${ }^{9,10,12}$. Status obesitas pada penelitian ini ditentukan dengan Waist-to-height ratio (WHtR). WHtR diketahui sensitif untuk mengukur jaringan lemak visceral dan risiko kesehatan yang ditimbulkan obesitas ${ }^{15,26}$. Kondisi obesitas visceral menyebabkan inflamasi kronis di tubuh yang ditandai dengan peningkatan sitokin-sitokin inflamasi serta sangat berkaitan dengan terjadinya resistensi insulin yang berkontribusi pada abnormalitas metabolitmetabolit dan penyakit jantung, termasuk juga stress oksidatif. Adanya abnormalitas metabolit-metabolit akibat disregulasi sitokin memicu aktivitas enzimenzim antioksidan seperti GPx yang membutuhkan selenium. Disregulasi yang terjadi secara kronis menyebabkan level selenium di tubuh akan semakin turun $^{27}$. Penurunan level selenium di tubuh bersamaan dengan penurunan aktivitas enzim GPx mungkin disebabkan adanya kondisi atherosklerotik dimana terjadi peningkatan konsumsi antioksidan oleh interaksi radikal bebas ${ }^{28}$. Sebuah studi juga menyebutkan bahwa akumulasi lemak dalam jaringan visceral dapat mengganggu konsentrasi dari elemenelemen essensial salah satunya selenium. Sitokinsitokin inflamasi disebutkan dapat menghambat ekspresi dari Se-transporter selenoprotein $P$ (SEPP1). SEPP1 merupakan transporter utama yang berperan membawa selenium yang telah diabsrobsi dari liver kembali ke sirkulasi darah ${ }^{20}$. SEPP1 merupakan pusat homeostasis selenium yang mengatur retensi selenium di tubuh dan 
mempengaruhi distribusi selenium dari liver ke jaringan. Adanya deplesi selektif dari ekspresi SEPP1 di hepatosit menyebabkan terganggunya suplai selenium ke jaringan tubuh dan menyebabkan defisiensi selenium ${ }^{29}$.

Kadar serum selenium pada kelompok stuntedobesity berada paling rendah dibanding kelompok lain. Hal ini dapat disebabkan oleh adanya peningkatan inflamasi maupun penurunan kapasitas antioksidan seperti vitamin C, vitamin E, dan selenium $^{30}$. Penurunan kapasitas antioksidan dapat disebabkan oleh rendahnya asupan zat gizi yang terkait dimana pada kelompok stunted-obesity, kecukupan asupan beberapa zat gizi berada paling rendah dibanding kelompok lain. Studi terdahulu menunjukkan bahwa kadar pro-inflamator high sensitive $C$-reactive protein (hsCRP) lebih tinggi pada remaja stunted obesity dibanding remaja dengan status gizi normal ${ }^{31}$. Terjadinya ketidakseimbangan energi positif menyebabkan ukuran adiposit akan membesar dan mengalami hipertropi dan jika berlangsung lama akan terjadi peningkatan jumlah adiposit terus menerus atau hiperplasia. Hal inilah yang terjadi pada individu stunted-obesity. Keadaan obesitas pada individu stunting memicu proses diferensiasi dari sel prekursor (preadiposit) menjadi adiposit yang matang. Jaringan adiposa mengalami inflamasi dan terdapat infiltrasi makrofag yang kemudian meningkatkan kondisi pro-inflamasi. Kondisi tersebut dapat menyebabkan ketidakseimbangan yang kemudian meningkatkan kondisi pro-inflamasi sehingga diferensiasi preadiposit gagal. Produksi sel-sel adiposa yang meningkat secara terus menerus diterjemahkan sebagai protein atau stimulus asing oleh mekanisme imun tubuh dan dideteksi sebagai radikal bebas yang mengancam tubuh ${ }^{32}$. Hal inilah yang memicu terjadinya inflamasi yang dapat berpengaruh terhadap kadar serum selenium.

WHtR sebagai indikator penentuan obesitas dalam penelitian ini berkorelasi negatif dengan kadar serum selenium. Hal ini berarti semakin besar nilai WHtR, maka kadar selenium pada subjek semakin rendah. Nilai WHtR menunjukan adanya obesitas sentral, dimana pada sebuah studi ditemukan bahwa jaringan adiposa pada orang obesitas berkaitan dengan peningkatan stress oksidatif dan penurunan aktivitas enzim-enzim antioksidan diantaranya GPx. Selain itu, adiposa yang berlebih menyebabkan kondisi pro-inflamasi yang mengakibatkan peningkatan kebutuhan selenium yang dapat berdampak pada perubahan kadar selenium jangkapanjang $^{33}$. Adanya pengurangan kadar selenium akibat inflamasi disebabkan oleh SEPP1 yang merupakan kontributor utama terhadap kadar selenium diketahui berkurang pada kondisi inflamasi ${ }^{34}$. Kondisi inflamasi yang dimediasi oleh sitokin proinflamator menekan produksi hepatik beberapa protein-protein karier, meningkatkan permeabilitas kapiler, dan menghambat masuknya beberapa mikronutrien ke liver dan organ lain. Hal ini juga terjadi pada selenium, dimana sebagian besar selenium yang beredar berbentuk SEPP1 yang juga termasuk protein karier dan produksinya menjadi berkurang ${ }^{34}$.

Terdapat hubungan yang signifikan antara kecukupan asupan protein dengan kadar serum selenium. Hal ini disebabkan protein dibutuhkan untuk selenium agar dapat berfungsi. Selenium bergabung dengan protein untuk selanjutnya diedarkan dalam sirkulasi. Selain itu, protein bersama dengan vitamin $\mathrm{C}$ dan vitamin $\mathrm{E}$ merupakan faktor yang meningkatkan absorbsi selenium di tubuh ${ }^{35}$. Asupan methionin mempengaruhi absorbsi selenium karena memiliki mekanisme absorbsi yang identik. Se-Met akan digunakan untuk mengganti methionin dalam sintesis protein sehingga meningkatkan Se jaringan dan menurunkan penggabungan selenium pada enzim spesifik seperti GPx ${ }^{36}$. Faktor lain yang dapat menjelaskan hubungan kecukupan protein dengan kadar selenium adalah adanya kemiripan sumber dari bahan makanan dimana sumber makanan tinggi selenium banyak terdapat pada makanan hewani yang mengandung protein dengan nilai bioavailabilitas yang tinggi. Vitamin $\mathrm{C}$ dan vitamin $\mathrm{E}$ merupakan antioksidan yang bersama dengan selenium berperan dalam pencegahan stress oksidatif. Hasil penelitian ini mendapatkan bahwa terdapat hubungan signifikan antara vitamin $\mathrm{C}$ dengan kadar serum selenium, namun hubungan yang signifikan tidak ditemukan antara vitamin $\mathrm{E}$ dengan kadar serum selenium. Vitamin $\mathrm{C}$ diketahui dapat meningkatkan bioavailabilitas selenium. Konsumsi vitamin $\mathrm{C}$ yang tinggi berdampak pada absorbsi fraksi selenite yang tinggi serta peningkatan retensi selenite. Hal ini disebabkan adanya proteksi vitamin $\mathrm{C}$ terhadap grup sulphydryl yang juga terlibat dalam uptake selenite di gastrointestinal $^{36} . \mathrm{Cu}, \mathrm{Zn}, \mathrm{Mn}$, dan $\mathrm{Fe}$ diketahui merupakan trace element yang sangat dibutuhkan sebagai kofaktor dari enzim-enzim antioksidan. Namun pada penelitian ini hanya kecukupan Mn yang ditemukan berhubungan signifikan dengan kadar serum selenium.

\section{KETERBATASAN PENELITIAN}

Keterbatasan penelitian ini adalah tidak dilakukannya pengukuran terhadap status inflamasi dan kadar selenoprotein-P. Selain itu laboratorium yang digunakan juga belum terakreditasi. Hal ini disebabkan terbatasnya ketersediaan sumber daya dan finansial dari peneliti. 


\section{SIMPULAN}

Rerata kadar serum selenium pada seluruh kelompok berada diatas nilai normal. Kadar serum selenium pada kelompok stunted-obesity dan non stunted-obesity lebih rendah dibanding kelompok non stunted-non obesity namun tidak bermakna secara statistik. Sedangkan kadar serum selenium pada kelompok stunted-non obesity lebih tinggi secara signifikan dibanding pada kelompok non stunted-non obesity dan mungkin disebabkan asupan selenium yang tinggi.

\section{SARAN}

Diharapkan penelitian ini dilanjukan dengan meneliti status stress oksidatif, inflamasi, dan kadar selenoprotein. Remaja yang mengalami stuntedobesity dan non stunted-obesity diharapkan meningkatkan konsumsi zat-zat gizi yang berperan antioksidatif sesuai kebutuhan serta menurunkan WHTR untuk menghindari masalah kesehatan lain.

\section{UCAPAN TERIMA KASIH}

Peneliti mengucapkan terima kasih kepada subjek penelitian yaitu mahasiswa-mahasiswi Universitas Diponegoro tahun ajaran 2017/2018.

\section{DAFTAR PUSTAKA}

1. Gower B, Caprio S. Puberty, Insulin Resistance $\&$ Type 2 Diabetes. In: Handbook of Pediatric Obesity: Etiology, Pathophysiology, and Prevention. Goran M, Sothern M, editors. Boca Raton: CRC Press Taylor \& Francis Publishing; 2006. p. $175-80$.

2. Alberga AS, Sigal RJ, Goldfield G, Prud Homme D, Kenny GP. Overweight and obese teenagers: Why is adolescence a critical period? Pediatr Obes. 2012;7(4):261-73.

3. Daniels SR, Arnett DK, Eckel RH, Gidding SS, Hayman LL, Kumanyika S, et al. Overweight in children and adolescents: Pathophysiology, consequences, prevention, and treatment. Circulation. 2005;111(15):1999-2012.

4. Badan Penelitian dan Pengembangan Kesehatan. Riset Kesehatan Dasar (RISKESDAS) 2013. Lap Nas 2013. 2013;1-384.

5. Hoffman DJ, Sawaya AL, Verreschi I, Tucker KL, Roberts SB. Why are nutritionally stunted children at increased risk of obesity? Studies of metabolic rate and fat oxidation in shantytown children from São Paulo, Brazil. Am J Clin Nutr. 2000;72:702-7.

6. Valentini Francisqueti F, Camargo Talon Chiaverini L, Carolo dos Santos K, Otavio Minatel I, Berchieri Ronchi C, Junio Togneri Ferron A, et al. The role of oxidative stress on The pathophysiology of metabolic syndrome.
Rev Assoc Med Bras. 2017;63(1):85-91.

7. Marseglia L, Manti S, D’Angelo G, Nicotera A, Parisi E, Di Rosa G, et al. Oxidative stress in obesity: A critical component in human diseases. Int J Mol Sci. 2015;16(1):378-400.

8. Tinggi U. Selenium: Its role as antioxidant in human health. Environ Health Prev Med. 2008;13(2):102-8.

9. Błażewicz A, Klatka M, Astel A, KoronaGlowniak I, Dolliver W, Szwerc W, et al. Serum and urinary selenium levels in obese children: A cross-sectional study. J Trace Elem Med Biol. 2015;29:116-22.

10. Azab SF, Saleh SH, Elsaeed WF, Elshafie MA, Sherief LM, Esh AM. Serum trace elements in obese Egyptian children: a case-control study. Ital J Pediatr. 2014;40(1):20.

11. Ortega M, Rodriguez-Rodriguez, Aparicio, Jimenez Ortega I, Palmeros, Perea M, et al. Young Children with Excess of Weight Show an Impaired Selenium Status. Int J Vitam Nutr Res. 2012;82:121-9.

12. Ghayour-mobarhan M, Taylor A, Lanham-new S. Serum Selenium and Glutathione Peroxidase in Patients with Obesity and Metabolic Syndrome. Pakistan J Nutr. 2008;7(1):112-7.

13. Samy G, Hamed A, Kamel M, Hamdi H, Erfan M, Abdallah HR. Oxidative stress status in nutritionally stunted children. Egypt Pediatr Assoc Gaz. 2014;62(1):28-33.

14. Estrella, Sempértegu, Vallejo, Herrera, Tapia, Moscoso, et al. Selenium Serum Concentrations in Malnourished Ecuadorian Children: A CaseControl Study. Int J Vitam Nutr Res. 2003;73:181-6.

15. Izze E, Ferreira L, Ana S, Priore SE. Waist circumference, waist/height ratio, and neck circumference as parameters of central obesity assessment in children. Rev Paul Pediatr. 2014;32(3):273-81.

16. Kementerian Kesehatan Indonesia. Standar Antropometri Penilaian Status Gizi Anak. 2010

17. Thomson CD. Assessment of requirements for selenium and adequacy of selenium status: $\mathrm{A}$ review. Eur J Clin Nutr. 2004;58(3):391-402.

18. Rükgauer M, Klein J, Kruse-Jarres J. Reference values for the trace elements copper, manganese, selenium, and zinc in the serum/plasma of children, adolescents, and adults. J Trace Elem Med Biol. 1997;11(2):92-8.

19. Mehdi Y, Hornick JL, Istasse L, Dufrasne I. Selenium in the environment, metabolism and involvement in body functions. Molecules. 2013;18(3):3292-311.

20. Combs GF. Biomarkers of selenium status. Nutrients. 2015;7(4):2209-36. 
21. Erdenetsogt E, Tarmaeba E, Bolormaa N, Tserenlham B, Jargal E, Batjargal J, et al. The Human Selenium Status in Mongolia. Trace Elem Med. 2015;16(1):11-4.

22. Lemire M, Mergler D, Fillion M, Passos CJS, Guimarães JRD, Davidson R, et al. Elevated blood selenium levels in the Brazilian Amazon. Sci Total Environ. 2006;366(1):101-11.

23. Kain J, Uauy R, Lera L, Taibo M, Albala C. Trends in height and BMI of 6-year-old children during the nutrition transition in Chile. Obes Res. 2005;13(12):2178-86.

24. Sawaya AL, Roberts S. Stunting and future risk of obesity: principal physiological mechanisms. Cad Saude Publica. 2003;19(suppl 1):S21-8.

25. Muhammad HFL. Obesity as the Sequel of Childhood Stunting: Ghrelin and GHSR Gene Polymorphism Explained. Acta Med Indones. 2018;50(2):159-64.

26. Ahmad N, Adam SIM, Nawi AM, Hassan MR, Ghazi HF. Abdominal obesity indicators: Waist circumference or waist-to-hip ratio in Malaysian adults population. Int J Prev Med. 2016;2016(June).

27. Kim HN, Song SW. Concentrations of chromium, selenium, and copper in the hair of viscerally obese adults are associated with insulin resistance. Biol Trace Elem Res. 2014;158(2):152-7.

28. Tajaddini MH, Keikha M, Razzazzadeh A, Kelishadi R. A systematic review on the association of serum selenium and metabolic syndrome. J Res Med Sci. 2015;20(8):782-9.
29. Mao J, Teng W. The relationship between selenoprotein $\mathrm{P}$ and glucose metabolism in experimental studies. Nutrients. 2013;5(6):1937-48.

30. Amirkhanlou S, Emadi $\mathrm{H}$, Eshghinia $\mathrm{S}$. Evaluation of Plasma Selenium Level and its Association with Malnutrition in Hemodialysis Patients in Golestan Province, Iran. J Clin Basic Res. 2017;1(1):17-21.

31. Moulia M, Sulchan M, Nisa C. Kadar Proinflamator High Sensitive C- Reactive Protein (hsCRP) pada Remaja Stunted Obese di SMA Kota Semarang. J Nutr Coll. 2013;2(2):44-9.

32. Ceperuelo-Mallafré V, Ejarque M, Serena C, Duran X, Montori-Grau M, Rodríguez MA, et al. Adipose tissue glycogen accumulation is associated with obesity-linked inflammation in humans. Mol Metab. 2016;5(1):5-18.

33. Bleys J, Navas-Acien A, Stranges S, Menke A, Miller E, Guallar E. Serum selenium and serum lipids in US adults. Am J Clin Nutr. 2009;250(4):634-41.

34. Duncan A, Talwar D, McMillan DC, Stefanowicz F, O'Reilly DSJ. Quantitative data on the magnitude of the systemic inflammatory response and its effect on micronutrient status based on plasma measurements. Am J Clin Nutr. 2012;95(1):64-71.

35. Surai PF. Selenium in Nutrition and Health. 1st ed. Surai PF, editor. Vol. 8. Nottingham: Nottingham University Press; 2007. 985-994 p.

36. Fairweather-Tait S, Hurrell RF. Bioavailability of Minerals and Trace Elements. Nutr Res Rev. 1996;9(1):295. 